\title{
Tropical convective transport and the Walker circulation
}

\author{
J. S. Hosking ${ }^{1, *}$, M. R. Russo ${ }^{1,2}$, P. Braesicke ${ }^{1,2}$, and J. A. Pyle ${ }^{1,2}$ \\ ${ }^{1}$ Centre for Atmospheric Science, University of Cambridge, Cambridge, UK \\ ${ }^{2}$ National Centre for Atmospheric Science, University of Cambridge, Cambridge, UK \\ *now at: British Antarctic Survey, Cambridge, UK \\ Correspondence to: J. S. Hosking (scott.hosking@atm.ch.cam.ac.uk)
}

Received: 28 March 2012 - Published in Atmos. Chem. Phys. Discuss.: 11 May 2012

Revised: 9 October 2012 - Accepted: 10 October 2012 - Published: 29 October 2012

\begin{abstract}
We introduce a methodology to visualise rapid vertical and zonal tropical transport pathways. Using prescribed sea-surface temperatures in four monthly model integrations for 2005, we characterise preferred transport routes from the troposphere to the stratosphere in a high resolution climate model. Most efficient transport is modelled over the Maritime Continent (MC) in November and February, i.e., boreal winter. In these months, the ascending branch of the Walker Circulation over the MC is formed in conjunction with strong deep convection, allowing fast transport into the stratosphere. In the model the upper tropospheric zonal winds associated with the Walker Circulation are also greatest in these months in agreement with ERA-Interim reanalysis data. We conclude that the Walker circulation plays an important role in the seasonality of fast tropical transport from the lower and middle troposphere to the upper troposphere and so impacts at the same time the potential supply of surface emissions to the tropical tropopause layer (TTL) and subsequently to the stratosphere.
\end{abstract}

\section{Introduction}

Identifying transport pathways of very short-lived halocarbons to the upper troposphere/lower stratosphere (UTLS) region is important for assessing stratospheric ozone depletion (Levine et al., 2007; Salawitch et al., 2005; Sturges et al., 2000). Especially important in this context are brominated organic compounds (e.g., bromoform), which can be readily oxidised to form highly ozone-depleting inorganic bromine compounds $\left(\mathrm{Br}_{\mathrm{y}}\right)$, see for example Hossaini et al. (2010). These compounds are thought to play a role in determining stratospheric ozone concentrations and influencing the dis- tribution of UTLS ozone, thereby affecting radiative heating and possibly regional-scale tropopause temperatures. Understanding regional changes in ozone, tropopause temperatures and stratospheric water vapour is crucial for future climate prediction, as shown for example in the context of the Asian summer monsoon (Braesicke et al., 2011) or the Tropical Tropopause Layer (TTL), see below.

Tropical convection can provide an efficient transport pathway from the boundary layer to the TTL (Fueglistaler et al., 2009), a distinct layer below the tropopause. Differences in the strength and vertical extent of tropical convection are important for the efficiency of convective transport into the UTLS (Aschmann et al., 2011). One important circulation pattern in this context is the Walker circulation. The Walker circulation is a tropical meridional circulation in which air at the surface flows from high pressure over the eastern Pacific (EP) to low pressure over the Maritime continent (MC). Air rises over the $\mathrm{MC}$ (in conjunction with strong convection), up to around an altitude of $13-14 \mathrm{~km}(\sim 150 \mathrm{hPa})$, and flows towards the EP region in the upper troposphere before descending back down to the lower troposphere (Bjerknes, 1969). European Centre for Medium-Range Weather Forecasting (ECMWF) reanalysis data (ERA-Interim; Dee et al., 2011) indicates that the Walker Circulation is strongest around the boreal winter months (NDJF; not shown) compared to the summer months (MJJA), and is also strongly linked to changes in sea-surface temperatures over the equatorial $\mathrm{Pa}$ cific, e.g., El Niño-Southern Oscillation (ENSO; Kousky et al., 1984; Jin and Kirtman, 2010). Biogenic sources of $\mathrm{Br}_{\mathrm{y}}$ precursors (such as bromoform and dibromomethane) vary regionally in the Tropics (Quack and Wallace, 2003) and consequently the spatial distribution of deep convection in conjunction with availability of precursor emissions will 
determine the resulting $\mathrm{Br}_{\mathrm{y}}$ amounts above the rising branch of the Walker circulation.

Here, we focus on a case study of convective transport using a global forecast model with idealised tracers to answer the questions: What are the preferred tropical pathways for surface to upper troposphere/lower stratosphere transport? How do the pathways, and their tracer transport efficiencies, differ over the seasons?

\section{Experimental design}

\subsection{Model description}

We use the UK Met Office Unified Model version 6.1 in a global forecast setup (Petch et al., 2007). The horizontal resolution is $\sim 0.83 \times 0.56$ degrees (N216, corresponding to a grid spacing of $\sim 60 \mathrm{~km}$ ). The vertical coordinate system is hybrid sigma-height with 38 levels and a model top at $\sim 40 \mathrm{~km}$. The vertical resolution around the height of the TTL is $\sim 1 \mathrm{~km}$ (i.e., between 10 and $17 \mathrm{~km}$ ). A comprehensive list of important physical parameterisations used in the model is given below.

The Boundary Layer parameterisation is non-local in unstable regimes (Lock et al., 2000). The convective parameterisation scheme is based on Gregory and Rowntree (1990) and is called by the model twice per time-step where the time-step adopted is $20 \mathrm{~min}$ - the default for the UM forecast setup. Both shallow and deep convection are included in the scheme. Cloud base closure for shallow convection is based on Grant (2001), and parameterised entrainment and detrainment rates for shallow convection are obtained from Grant and Brown (1999). For deep convection, the thermodynamic closure is based on the reduction of the convectively available potential energy, CAPE, to zero (CAPE closure approach) based on Fritsch and Chappell (1980a, b). The CAPE timescale, which determines the e-folding time for the dissipation of CAPE, is set to the tried and tested default value of $30 \mathrm{~min}$ (i.e., the cloud based mass flux is relaxed to an equilibrium state over 1.5 time-steps where the convection scheme is called 3 times). A detailed representation of cloud microphysics is achieved using physically based parameterisation for transfers between the different categories of hydrometeors (Wilson and Ballard, 1999). Radiative transfer is calculated using the Edwards-Slingo radiation scheme (Edwards and Slingo, 1996).

\subsection{Model runs and validation}

Four model runs of 30 days each are performed using initial conditions from the UK Met Office's assimilated data for February, May, August and November 2005, as discussed in Hosking et al. (2010). They find that modelled temporal and spatial distribution of low OLR, which is one indicator of tropical convection, correlates well with satellite observations. The vertical and spatial distribution of fast ver-

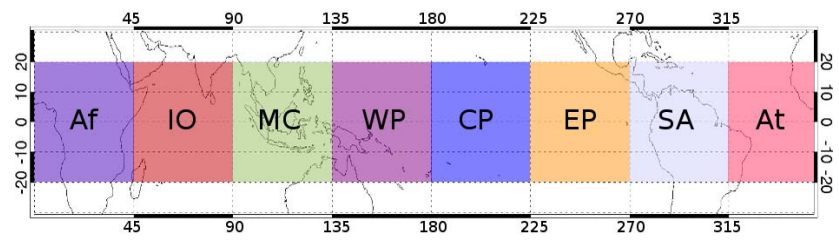

Fig. 1. The 8 tropical domains used for seasonal and regional tracer transport analysis; Africa (Af), Indian Ocean (IO), Maritime Continent (MC), West Pacific (WP), Central Pacific (CP), East Pacific (EP), South America (SA) and Atlantic (At). All domains are of equal size of between $20^{\circ} \mathrm{N}-20^{\circ} \mathrm{S}$ and $45^{\circ}$ in longitude.

tical transport of these relatively short-lived surface emitted tracers is also in good agreement with the convective mass flux diagnostics shown in Fig. 7 in Hosking et al. (2010). In this study, deep convective elevators rapidly lift air from 4-5 km up to $12-14 \mathrm{~km}$, and the influx of tropospheric air entering the TTL $(11-12 \mathrm{~km})$ is similar for all tropical regions, with only the deepest convection exceeding $14 \mathrm{~km}$. The model also captures the seasonality of the zonal components of the Walker Circulation within the TTL with higher wind speeds around the boreal winter months (NDJF) as indicated by analysis of $32 \mathrm{yr}$ of ERA-Interim data (not shown). We therefore assume that the model captures aspects of convective and zonal transport within the tropics for a neutral ENSO year well. Russo et al (2011) assessed tropical convection within a range of nine different models and found that the model setup used here also captured the observed vertical and regional distribution of convection well.

\section{Key diagnostic}

Here, we assess the transport of 8 idealised tracers emitted at the surface in a latitude band of $20^{\circ} \mathrm{N}-20^{\circ} \mathrm{S}$ around the equator from the 8 tropical domains illustrated in Fig. 1. Each of the domains is $45^{\circ}$ wide and is identified by a two letter acronym: Africa (Af), Indian Ocean (IO), etc. Each tracer is constantly emitted from the surface with a horizontally homogeneous flux of $1.0 \times 10^{-9} \mathrm{~kg} \mathrm{~m}^{-2} \mathrm{~s}^{-1}$ and has an infinite atmospheric lifetime thereafter. Vertical distributions of the eight tracers are analysed using time mean mass mixing ratios for identical periods from each of the 30-day long model integrations. Results presented here do not rely on the chosen period, for example analysing days 21 to 30 (used in the following) provides a nearly indistinguishable result to analysing days 19 to 28 , and the sensitivity to the period length (e.g., 5 versus 10 days) is also small.

Figure 2 shows an example of the mass mixing ratio of a tracer (shaded) emitted in the MC region in a longitudeheight cross-section averaged over the tropical belt $\left(20^{\circ} \mathrm{N}-\right.$ $20^{\circ} \mathrm{S}$ ) and averaged over the last 10 days of a monthly integration (started at 00:00 UT, 1st November 2005). The model converts the prescribed emissions into concentrations and the 


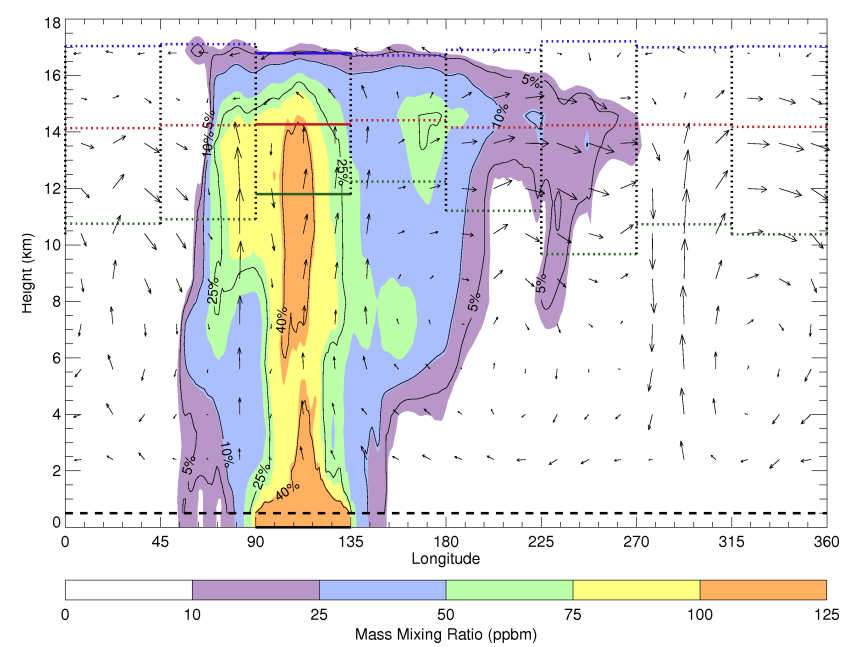

Fig. 2. Longitude-height distribution of a surface emitted tracer with an infinite lifetime from the Maritime Continent domain (MC). The tracer distribution is averaged between latitudes $20^{\circ} \mathrm{N}-20^{\circ} \mathrm{S}$ over the last 10 days in the November integration. (1) mass mixing ratios (shading) and (2) percentages (black contours) relative to the mean mass mixing ratio of all 8 tracers over all 8 regions at $0.5 \mathrm{~km}$ (long-dashed black line). TTL surfaces are here defined by the LRM (green lines), $\mathrm{Q}_{\text {clear }}=0$ level (red lines) and CPT (blue lines). The TTL surfaces represented by the solid lines highlight the receptor regions which correspond to vertical transport for this tracer. Wind vectors are arbitrarily scaled for the best visual representation of flow.

winds advect the concentrations horizontally and vertically. The emphasis will be on the vertical transport with some consideration regarding the horizontal transport within the TTL. We have chosen three model surfaces to monitor vertical transport, as expressed by increases in tracer concentrations during the integration period. The first surface is the lapse rate minimum (LRM) which varies regionally between 10 and $12 \mathrm{~km}$. The next surface is the level of clear-sky net-zero radiative heating $\left(\mathrm{Q}_{\mathrm{clear}}=0\right)$ at around $14 \mathrm{~km}$ and the top surface is at the model's (tropical) cold point tropopause (CPT), see also Hosking et al. (2010) for more details. In the example shown in Fig. 2, high relative tracer concentrations are found in the lower TTL, and coherently high mixing ratios are modelled at all altitudes below $15 \mathrm{~km}$ over the MC region, indicating efficient vertical transport. Consequently, high concentrations $(\sim 30 \%$ relative to the mean mass mixing ratio of all 8 tracers over all 8 regions at $0.5 \mathrm{~km}$ ) are modelled over the MC region at the LRM (solid green line) and the $\mathrm{Q}_{\text {clear }}=0$ level (solid red line), with lower concentrations $(\sim 5 \%)$ at the CPT level (solid blue line). We introduce the following notation: $\mathrm{MC}_{\text {surf }} \rightarrow \mathrm{MC}_{\mathrm{LRM}}$, etc., to indicate a local vertical transport pathway between the surface and the LRM level in the Maritime Continent region.

Figure 2 also indicates horizontal eastward tracer advection within the TTL from the MC region to the WP, CP and EP regions; such transport pathways are a combination of

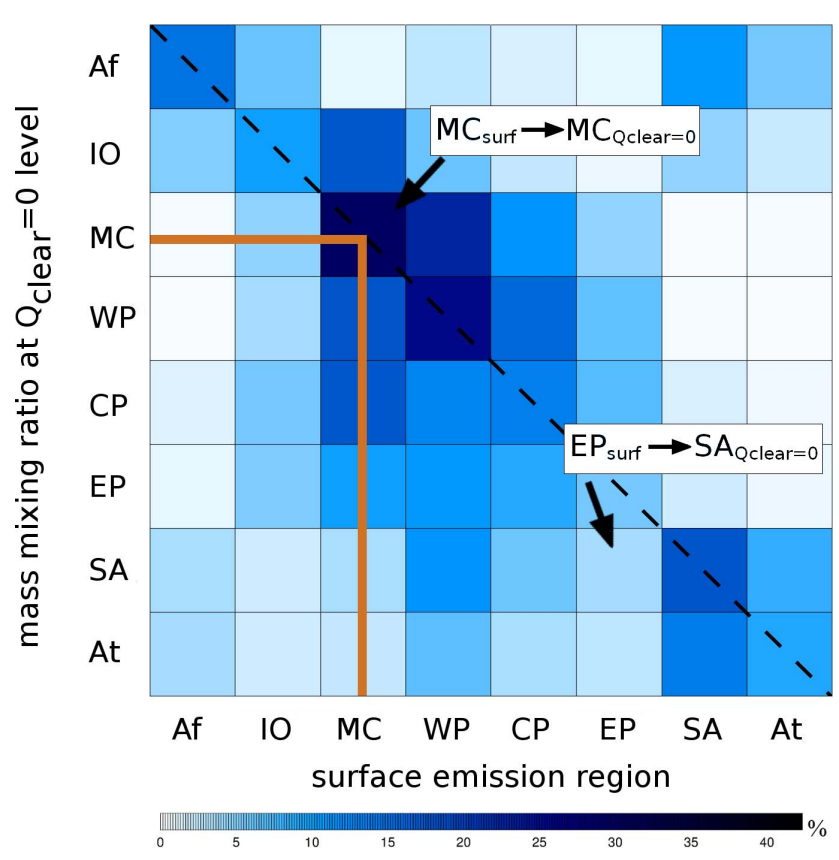

Fig. 3. A "surface-TTL" matrix where the boxes represent tropical transport of 8 surface emitted tracers ( $\mathrm{x}$-axis) to the same 8 regions (y-axis) at the $\mathrm{Q}_{\text {clear }}=0$ level - here shown for the November integration. The relative mean mass mixing ratio (see Fig. 2) in each box is represented by colour intensity in accordance to the range shown by the colour-scale below the matrix. The dotted black line illustrates the boxes where high concentrations would indicate efficient vertical transport of the tracers from their surface regions to the $\mathrm{Q}_{\text {clear }}=0$ level.

vertical and horizontal motion. A tracer emitted in one region appears after a certain time at a higher altitude over another region. Such vertical and horizontal transport pathways are indicated as $\mathrm{MC}_{\text {surf }} \rightarrow \mathrm{WP}_{\text {Qclear }=0}, \mathrm{MC}_{\text {surf }} \rightarrow \mathrm{CP}_{\text {Qclear }=0}$ and $\mathrm{MC}_{\text {surf }} \rightarrow \mathrm{EP}_{\mathrm{Qclear}=0}$. This notation will be extensively used to compare the dominance of different transport pathways in different months. It should be noted that the eastward zonal winds in the TTL form part of the Walker circulation. The descending branch of the Walker circulation is indicated by enhanced $M_{\text {surf }}$ mass mixing ratios between 8 and $12 \mathrm{~km}$ at the CP/EP border. We will come back to the influence of the Walker circulation in the discussion of the transport summary below.

In order to identify efficient transport pathways we analyse the mass mixing ratios of all tracers at a representative height in the TTL by constructing an $8 \times 8$ matrix, indicating the emission regions on the $\mathrm{x}$-axis and the receptor regions (at a certain altitude corresponding to one of the three vertical levels defined above) on the y-axis. An example is given in Fig. 3. Each square corresponds to one of the possible transport pathways between the 8 regions defined in our experiment, here for the month of November and for the $\mathrm{Q}_{\text {clear }=0}$ level around $14 \mathrm{~km}$. Conceptually, this methodology is a source-receptor relationship to identify 

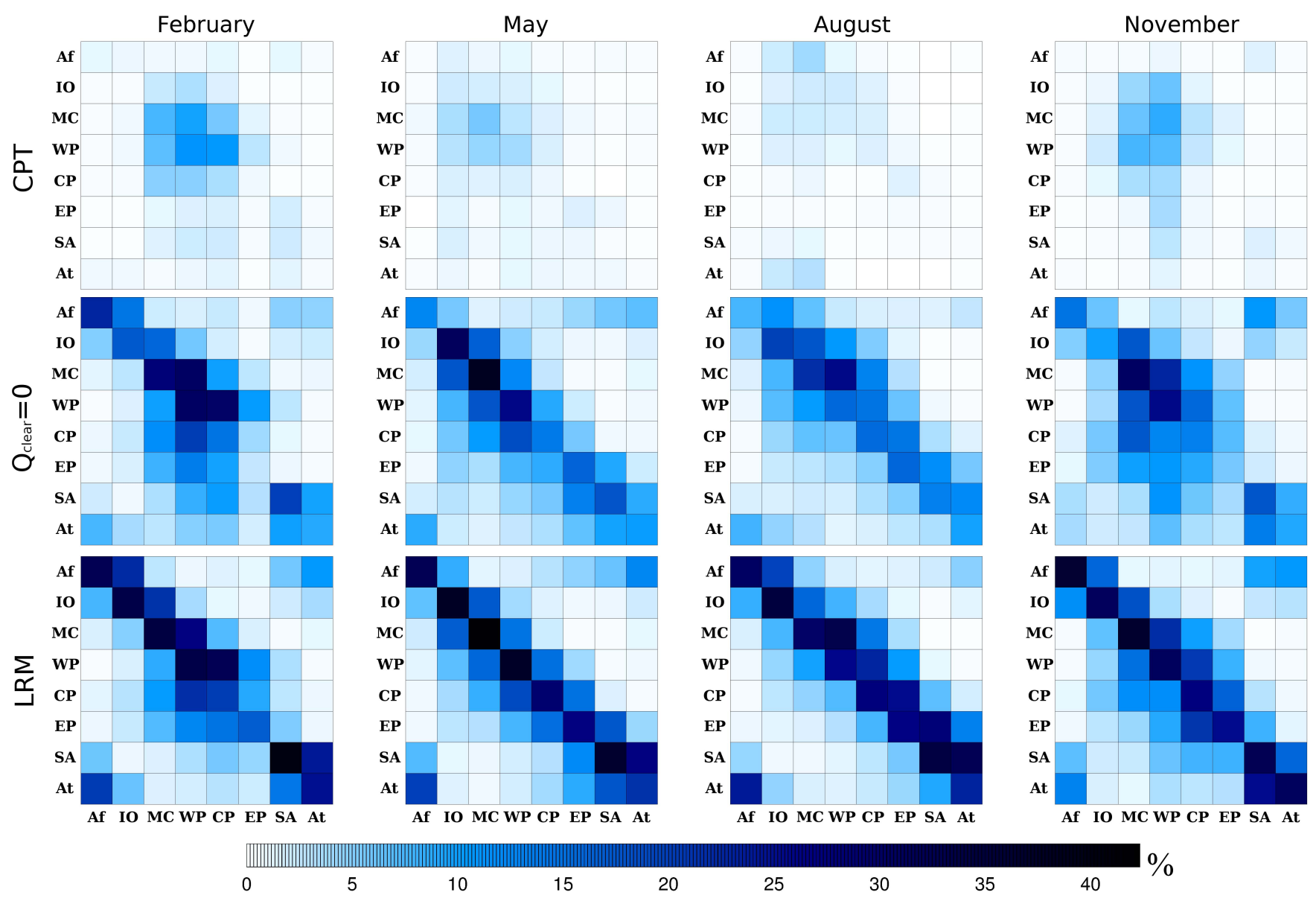

Fig. 4. Matrices that represent tropical transport pathways of 8 regional surface emitted tracers (x-axis) to the same 8 regions (y-axis) for 3 levels in the TTL; LRM, $\mathrm{Q}_{\text {clear }}=0$ and the CPT - shown by the 3 rows. Results are shown for the mean over the last 10 days for the February, May, August and November 2005 integrations. Darker colours represent high relative mass mixing ratios (see Fig. 2).

likely pathways from a source region at the surface (x-axis) to receptor regions (y-axis) at a certain altitude. High tracer mixing ratios (dark blue colours) indicate that the transport pathway is relatively efficient (e.g., $\mathrm{MC}_{\text {surf }} \rightarrow \mathrm{MC}_{\mathrm{Qclear}=0}$ ) with lighter colours indicating less efficient transport pathways (e.g., $\mathrm{EP}_{\text {surf }} \rightarrow \mathrm{SA}_{\text {Qclear=0 }}$ ). Again, concentrations are given in percent relative to the near-surface mean, defined as the average tracer concentration of all 8 tracers over all 8 regions at $0.5 \mathrm{~km}$. The boxes on the matrix diagonal indicate vertical transport pathways, while boxes off the diagonal indicate vertical and zonal transport pathways.

In the next section we use matrices constructed in this way - for four different months in 2005 and for the three characteristic levels in the TTL - to identify the model's preferred transport pathways from the surface to the TTL and their seasonality.

\section{Patterns of tracer transport through the TTL}

Figure 4 compares the matrices at the LRM, the $\mathrm{Q}_{\text {clear }}=0$ and the CPT levels (rows, from bottom to top) for all four months (columns). A broad overview of the seasonal and regional variations in mass transport can now be easily seen. The short (30 day) model integrations were designed to highlight fast transport mechanisms (e.g., convective uplift in the boundary layer and the free troposphere) into the TTL; transport driven by the slower, seasonal transport regimes (e.g., radiatively driven ascent) is not captured by our analysis. Consequently, the matrices highlight the modelled pathways which are potentially important for the transport of short-lived surface emitted species into the TTL and directly into the stratosphere. Starting from the base of the TTL, we will next use the matrices in Fig. 4 to discuss the modelled tracer transport, from the surface to the three TTL surfaces, and how they evolve as a function of altitude and season. 


\subsection{Matrices at the lapse rate minimum}

In all four months analysed we find a pronounced diagonal at the LRM level, indicating a large local impact on the TTL composition. This agrees with our general notion that the horizontal west-east transport at this altitude is fairly weak (see wind vectors in Fig. 2), which agrees well with a classic Walker Circulation cell (Bjerknes, 1969) with eastward flow above the LRM level and westward flow near the surface. For most regions there is no marked seasonal cycle in the location of influx of surface emitted tracers into the TTL. In the model, tropical transport from the surface up to the base of the TTL is dominated by large-scale upwelling and detrainment. The results suggest that much of the seasonal variation of short-lived surface emitted species observed in the lower TTL is potentially dominated by the magnitude of emission fluxes and their longitudinal variation rather than greater convective activity. Note that Levine et al. (2007) diagnosed in a chemistry-transport model that short-lived surface tracers preferentially cross the lower TTL boundary (defined at a height of around $340 \mathrm{~K}, \sim 12 \mathrm{~km}$ in their work) over the Maritime Continent where vertical velocities are higher, whereas our results do not reveal such a preferential area at this altitude for a tracer of infinite lifetime. However, as shown in Russo et al. (2011), the model used in Levine et al. (2007) underestimated the percentage of convective cloud tops reaching above $\sim 12 \mathrm{~km}$ and the height of mean convective outflow, whereas the model used here compares well with observational evidence of high reaching convection (Russo et al., 2011), lending credibility to the transport pattern inferred in Fig. 4.

\subsection{Matrices at the level of zero clear-sky net radiative heating}

The strong diagonal seen at the LRM weakens at the $\mathrm{Q}_{\text {clear }}=0$ level as it is generally higher than the model's level of mean convective outflow (see Hoyle et al., 2011 and the discussions therein). The matrices now highlight these limited regions of deep and frequent convective transport reaching up to and above the $\mathrm{Q}_{\text {clear }}=0$ level. In February and November, the highest mixing ratios originate from the $\mathrm{MC}$, WP and $\mathrm{CP}$ regions, whereas in May and August the highest mixing ratios are coming from the IO, MC and WP regions. These tracers preferentially go through the lower part of the TTL in the same broad regions as their emissions (e.g., $\mathrm{MC}_{\text {surf }} \rightarrow \mathrm{MC}_{\mathrm{Qclear}=0}$ ). Vertical (ondiagonal) transport from the surface up to the upper TTL (above $\mathrm{Q}_{\text {clear }}=0$ ) dominates over zonal (off-diagonal) mixing on time-scales considered here. In February and November the off-diagonal eastward transport from the $\mathrm{MC}_{\text {surf }}$ and $\mathrm{WP}_{\text {surf }}$, which is associated with the Walker circulation, is highlighted by the dark to light blue colour gradient i.e., eastward pathways of steadily decreasing mass over

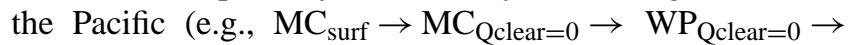

$\left.\mathrm{CP}_{\text {Qclear }=0} \rightarrow \mathrm{EP}_{\text {Qclear }=0}\right)$. This modelled transport appears to be greater in February and November which agrees with analysis of ERA-Interim data (not shown) and by model studies by Jin and Kirtman (2010) who find that zonal winds in the TTL region are stronger in the boreal winter months compared to the summer.

\subsection{Matrices at the cold point tropopause}

As expected, no pronounced diagonal is found at the CPT level, but in February and November relatively high concentrations of the MC and WP tracers are shown indicating some regional fast and deep vertical transport (e.g. $\left.\mathrm{MC}_{\text {surf }} \rightarrow \mathrm{MC}_{\mathrm{CPT}}\right)$. This pathway is potentially important for VSLS budgets as the Maritime Continent, with its shallow warm coastal waters and high bio-productivity, is a potentially rich source of short-lived brominated species (e.g., Quack, 2004; Warwick et al., 2006; Pyle et al., 2011). As was found at the $\mathrm{Q}_{\text {clear }}=0$ level, there is some seasonality associated with the Walker circulation; with off-diagonal enhanced tracer mixing ratios downwind from the source regions during February and November (compare LRM level matrices and Figure 2). In contrast, convection is not as deep in May and August as it is in February and November within the $20^{\circ} \mathrm{N}-20^{\circ} \mathrm{S}$ tropical belt shown by relatively lower mass mixing ratios at the CPT level.

\section{Conclusions}

The patterns of tropical fast transport pathways, as deduced from the matrices in Fig. 4, highlight regions and seasons of preferential entry of surface-emitted ozone depleting shortlived species into the stratosphere. As shown by Hosking et al. (2010) and Russo et al. (2011), we find that the model used here captures important aspects of convective transport for the analysed neutral ENSO year, 2005.

In these model experiments, almost all tropical regions contribute similar amounts of surface emitted tracers through the base of the TTL at the level of the lapse rate minimum (LRM). This is shown by pronounced diagonals in the matrices in Fig. 4. Over most regions, above this level, the horizontal component of tracer transport increases as fast vertical transport becomes less efficient. However, in regions of deep convection tracers are still lifted rapidly up to the level of net-zero radiative heating $\left(\mathrm{Q}_{\text {clear }}=0\right)$ in all months analysed. Tracers do reach the tropopause level within 21 to 30 days but only during February and November over the Maritime Continent and the West Pacific. As the tropical tropopause region is colder and drier between November and February (Mote et al., 1996; Newell and Gould-Stewart, 1981; Robinson, 1980), scavenging of halogenated short-lived compounds by ice and liquid water is likely reduced, allowing a higher fraction of $\mathrm{Br}_{\mathrm{y}}$ to reach the stratosphere then (Sinnhuber and Folkins, 2006). Vertical transport from the surface to 
the tropical tropopause over Africa and South America is weaker in comparison. This differs from the findings of Liu and Zipser (2005) who reported similar frequencies of convective clouds over-reaching about $14 \mathrm{~km}$ over Africa, the Maritime Continent and South America, as diagnosed from satellite measured ice reflectivity. From these data they argue that convective mass transport and the detrainment of tropospheric air above $14 \mathrm{~km}$ is comparable across these regions. However, there are still two open questions that require further investigation. Firstly, the assumption that the amount of ice particle formation is similar between the Maritime Continent region and the regions of Africa and South America even though the availability of water vapour and consequently latent heat may be somewhat different. For example, the regional tropopause over the Maritime Continent is relatively colder and drier than in other regions (Newell and Gould-Stewart, 1981; Hosking et al., 2010). Secondly, their analysis does not provide insight into the mean height of entrainment into the convective towers and so the amount of surface material that will detrain from deep convection in the TTL cannot be quantified. So in the model, the coherent occurrence of convection in conjunction with the Walker Circulation seems to be the key drivers of transport from the surface to the TTL.

Our results highlight the importance of the Walker circulation in redistributing MC injected VSLS horizontally in the lower TTL and the possibility of direct regional injections into the lower-most stratosphere (Fig. 2). In February and November, greater upwelling near the West Pacific enhances the Walker Circulation and consequently increases downwelling over the East Pacific. During an El Niño (La Niña) period the upwelling branch of the Walker Circulation would change as convection shifts eastward (westward). Further work is required to understand the full impact of the Walker Circulation variability, its interaction with deep tropical convection and transport of ozone depleting substances which is fundamental for improving future stratospheric chemistry and climate predictions.

Acknowledgements. This work was supported by the NERCfunded National Centre for Atmospheric Science (NCAS), and J. S. H gratefully acknowledges an e-Science studentship, supported by NERC. We thank David Jackson from the MO for providing the initial conditions for the model from the data assimilation system. Furthermore, we would like to thank Paul Telford from the University of Cambridge and Charles Chemel from University of Hertfordshire for their helpful advice throughout.

Edited by: G. Vaughan

\section{References}

Aschmann, J., Sinnhuber, B.-M., Chipperfield, M. P., and Hossaini, R.: Impact of deep convection and dehydration on bromine loading in the upper troposphere and lower stratosphere, Atmos. Chem. Phys., 11, 2671-2687, doi:10.5194/acp-11-26712011, 2011.

Bjerknes, J.: Atmospheric teleconnections from the equatorial Pacific. Mon. Wea. Rev., 97, 163-172, 1969.

Braesicke, P., Smith, O. J., Telford, P., and Pyle, J. A.: Ozone concentration changes in the Asian summer monsoon anticyclone and lower stratospheric water vapour: An idealised model study, Geophysical Research Letters, 38(3), L03810, doi:10.1029/2010GL046228, 2011.

Edwards, J. and Slingo, A.: Studies with a flexible new radiation code. I: Choosing a configuration for a large-scale model, Q. J. Roy. Meteorol. Soc., 122, 689-719, 1996.

Dee, D. P., Uppala, S. M., Simmons, A. J., Berrisford, P., Poli, P., Kobayashi, S., Andrae, U., Balmaseda, M. A., Balsamo, G., Bauer, P., Bechtold, P., Beljaars, A. C. M., van de Berg, L., Bidlot, J., Bormann, N., Delsol, C., Dragani, R., Fuentes, M., Geer, A. J., Haimberger, L., Healy, S. B., Hersbach, H., Hólm, E. V., Isaksen, L., Kållberg, P., Köhler, M., Matricardi, M., McNally, A. P., Monge-Sanz, B. M., Morcrette, J.-J., Park, B.-K., Peubey, C., de Rosnay, P., Tavolato, C., Thépaut, J.-N. and Vitart, F.: The ERA-Interim reanalysis: configuration and performance of the data assimilation system. Q. J. Roy. Meteorol. Soc., 137, 553597. doi:10.1002/qj.828, 2011

Fritsch, J. and Chappell, C.: Numerical prediction of convectively driven mesoscale pressure systems. I: Convective parameterization, J. Atmos. Sci., 37, 1722-1733, 1980a.

Fritsch, J. and Chappell, C.: Numerical prediction of convectively driven mesoscale pressure systems. II: Mesoscale model, J. Atmos. Sci., 37, 1734-1762, 1980b.

Fueglistaler, S., Dessler, A. E., Dunkerton, T. J., Folkins, I., Fu, Q., and Mote, P. W.: Tropical tropopause layer, Rev. Geophys., 47, RG1004, doi:10.1029/2008RG000267, 2009.

Grant, A.: Cloud-base fluxes in the cumulus-capped boundary layer, Q. J. Roy. Meteorol. Soc., 127, 407-421, 2001.

Grant, A. L. M. and Brown, A. R.: A similarity hypothesis for shallow-cumulus transports, Q. J. Roy. Meteorol. Soc., 125, 1913-1936, 1999.

Gregory, D. and Rowntree, P.: A mass flux convection scheme with representation of cloud ensemble characteristics and stability dependent closure, Mon. Weather Rev., 118, 1483-1506, 1990.

Hosking, J. S., Russo, M. R., Braesicke, P., and Pyle, J. A.: Modelling deep convection and its impacts on the tropical tropopause layer, Atmos. Chem. Phys., 10, 11175-11188, doi:10.5194/acp10-11175-2010, 2010.

Hossaini, R., Chipperfield, M. P., Monge-Sanz, B. M., Richards, N. A. D., Atlas, E., and Blake, D. R.: Bromoform and dibromomethane in the tropics: a 3-D model study of chemistry and transport, Atmos. Chem. Phys., 10, 719-735, doi:10.5194/acp-10-719-2010, 2010.

Hoyle, C. R., Marécal, V., Russo, M. R., Allen, G., Arteta, J., Chemel, C., Chipperfield, M. P., D'Amato, F., Dessens, O., Feng, W., Hamilton, J. F., Harris, N. R. P., Hosking, J. S., Lewis, A. C., Morgenstern, O., Peter, T., Pyle, J. A., Reddmann, T., Richards, N. A. D., Telford, P. J., Tian, W., Viciani, S., Volz-Thomas, A., Wild, O., Yang, X., and Zeng, G.: Repre- 
sentation of tropical deep convection in atmospheric models Part 2: Tracer transport, Atmos. Chem. Phys., 11, 8103-8131, doi:10.5194/acp-11-8103-2011, 2011.

Jin, D. and Kirtman, B. P.: How the annual cycle affects the extratropical response to ENSO, J. Geophys. Res., 115, D06102, doi:10.1029/2009JD012660, 2010

Kousky, V. E., Kagano, M. T., and Cavalcanti, I. F. A.: A review of the Southern Oscillation: oceanic-atmospheric circulation changes and related rainfall anomalies. Tellus A, 36A: 490504. doi:10.1111/j.1600-0870.1984.tb00264.x, 1984

Levine, J. G., Braesicke, P., Harris, N. R. P., Savage, N. H., and Pyle, J. A.: Pathways and timescales for troposphere-to-stratosphere transport via the tropical tropopause layer and their relevance for very short lived substances, J. Geophys. Res., 112, 1-15, doi:10.1029/2005JD006940, 2007

Liu, C. and Zipser, E. J.: Global distribution of convection penetrating the tropical tropopause, J. Geophys. Res., 110, D23104, doi:10.1029/2005JD006063, 2005

Lock, A. P., Brown, A. R., Bush, M. R., Martin, G. M., and Smith, R. N. B.: A new boundary layer mixing scheme. Part I: Scheme description and single-column model tests, Mon. Weather Rev., 128, 3187-3199, 2000.

Mote, P. W., Rosenlof, K. H., Mclntyre, M. E., Carr, E. S., Gille, J. C., Holton, J. R., Kinnersley, J. S., Pumphrey, H. C., Russell III, J. M., and Waters, J. W.: An atmospheric tape recorder: The imprint of tropical tropopause temperatures on stratospheric water vapor, J. Geophys. Res., 101, 3989-4006, doi:10.1029/95JD03422, 1996.

Newell, R. E. and Gould-Stewart, S.: A Stratospheric Fountain?, J. Atmos. Sci., 38, 2789-2796, doi:10.1175/1520-0469(1981)038, 1981.

Petch, J. C., Willett, M., Wong, R. Y., and Woolnough, S. J.: Modelling suppressed and active convection. Comparing a numerical weather prediction, cloud-resolving and single-column model, Q. J. Roy. Meteorol. Soc., 133, 1087-1100, doi:10.1002/qj.109, 2007.

Pyle, J. A., Ashfold, M. J., Harris, N. R. P., Robinson, A. D., Warwick, N. J., Carver, G. D., Gostlow, B., O’Brien, L. M., Manning, A. J., Phang, S. M., Yong, S. E., Leong, K. P., Ung, E. H., and Ong, S.: Bromoform in the tropical boundary layer of the Maritime Continent during OP3, Atmos. Chem. Phys., 11, 529542, doi:10.5194/acp-11-529-2011, 2011.
Quack, B.: Oceanic bromoform sources for the tropical atmosphere, Geophys. Res. Lett., 31, 23-26, doi:10.1029/2004GL020597, 2004

Quack, B. and Wallace, D. W. R.: Air-sea flux of bromoform: Controls, rates, and implications, Global Biogeochem. Cy., 17, 1023, doi:10.1029/2002GB001890, 2003

Robinson, G. D.: The transport of minor atmospheric constituents between troposphere and stratosphere, Q. J. Roy. Meteorol. Soc., 106, 227-253, doi:10.1002/qj.49710644802, 1980

Russo, M. R., Marécal, V., Hoyle, C. R., Arteta, J., Chemel, C., Chipperfield, M. P., Dessens, O., Feng, W., Hosking, J. S., Telford, P. J., Wild, O., Yang, X., and Pyle, J. A.: Representation of tropical deep convection in atmospheric models - Part 1: Meteorology and comparison with satellite observations, Atmos. Chem. Phys., 11, 2765-2786, doi:10.5194/acp-11-27652011, 2011.

Salawitch, R. J., Weisenstein, D. K., Kovalenko, L. J., Sioris, C. E., Wennberg, P. O., Chance, K., Ko, M. K. W., and Mclinden, C. A.: Sensitivity of ozone to bromine in the lower stratosphere, Geophys, Res. Lett., 32, L05811, doi:10.1029/2004GL021504, 2005

Sinnhuber, B.-M. and Folkins, I.: Estimating the contribution of bromoform to stratospheric bromine and its relation to dehydration in the tropical tropopause layer, Atmos. Chem. Phys., 6, 4755-4761, doi:10.5194/acp-6-4755-2006, 2006.

Sturges, W., Oram, D. E., Carpenter, L. J., Penkett, S. A., and Engel, A.: Bromoform as a source of stratospheric bromine, Geophysical Research Letters, 27, 2081-2084, doi:10.1029/2000GL011444, 2000

Warwick, N. J., Pyle, J. A., Carver, G. D., Yang, X., Savage, N. H., O'Connor, F. M., and Cox, R. A.: Global modeling of biogenic bromocarbons, J. Geophys. Res., 111, 24305, doi:10.1029/2006JD007264, 2006

Wilson, D. R. and Ballard, S. P.: A microphysically based precipitation scheme for the UK Meteorological Office Unified Model, Q. J. Roy. Meteorol. Soc., 125, 1607-1636, 1999. 